\title{
Media and Communication Approaches to Leaving Religion
}

\author{
Teemu Taira
}

\section{Introducing Media and Communication Approaches to Leaving Religion}

Long research traditions exist behind both the theorisation of the relationship between religion and media (Arthur 1993; Hoover and Lundby 1997; Mitchell and Marriage 2003; Lynch et al. 2012) and that of the conversion to and renunciation of religion. For some reason, however, these two traditions have rarely overlapped. Neither in the study of leaving religion nor in that of religious conversion-one of the main research areas in the psychology of religion and religious experience- - has there been a focus on the role of media. There is, for instance, no chapter on media in The Oxford Handbook of Religious Conversation (Rambo and Farhadian 2014), and the word "media" is not even indexed in the volume, though "internet" is. One of the reasons might be that the studies of converting to and renouncing religion have focused on individuals- their life stories, psychological factors and social status-ignoring some of the factors that facilitate and influence those individuals' decision-making. While media cannot be said to be the main reason behind or motivation for renouncing any given religion, it is nevertheless crucial not to discount its role in facilitating the leaving of religion and maintaining the apostate's new identity. As research focusing primarily on the significance of the role played by media in one's decision to leave religion is scarce, the main aim of this chapter is to provide some tools for thinking about the relevance of media and communication to leaving religion. Most of the views presented here apply primarily to countries with relatively free and uncensored media and access to online media.

There are many ways to map how to study the role of media in leaving religion; this chapter focuses on media logics, media discourses and media use. The reason for this three-pronged approach is that these areas cover a broad range of 
material, from the very abstract level of media logics to more concrete ways in which media facilitates and, in some cases, prompts people to leave religion.

The concept of media logic refers, in its early formulation, to the production of media culture in general and to news in particular and its influence on different areas of life (Altheide and Snow 1979). In studies concerning religion and media, the media logic has been discussed by focusing on the concept of mediatisation. Mediatisation refers to the development of media as a semiautonomous institution which begins to direct the ways in which people relate to other areas of life and what information they get out of particular areas of life. In the context of religion, mediatisation has been forcefully argued for by Stig Hjarvard (2012, 2013), according to whom, the outcome of mediatisation of religion is "a new social and cultural condition in which the power to define and practice religion has been altered" (Hjarvard 2013: 83). This new condition means that media as an institution, rather than face-to-face contacts between believers or authorities of religious institutions, provides the primary interface for information about religion. That is, media not only transmits information but also takes an active role in the producing and framing religious issues. Furthermore, media tends to favour secular views over religious ones, thus adding pressure for religious groups and institutions to retain their adherents (Castells 2002: 406). Although this development does not explain why individuals leave religion or switch from one to another, it suggests that the ways in which media operates may have a secularising impact.

It is, nevertheless, debatable whether media does indeed play a strong secularising role. This is because the mainstream media tends to be a liberalising rather than simply a secularising force (Taira 2015), and religious authority may be exercised in previously unseen ways through new media technologies (Herbert 2011: 635-637; Larsson 2011). However, Hjarvard's perspective on the mediatisation of religion provides a theoretical framework for thinking about and testing the media's operating logic and its role in facilitating the leaving of religion in contemporary societies.

In some cases, the mainstream media takes a position of defending the dominant religion (Knott et al. 2013). For instance, after a trend emerged of individuals renouncing the Evangelical-Lutheran Church of Finland because of comments made on television in a current affairs programme about the rights of homosexuals in 2010, mainstream newspapers, in spite of their wish to take the liberal rather than conservative side in the debate, explicitly encouraged people not to leave the church, arguing that change had to be effected from within not without the church. In this case, the logic of news production in highlighting conflicts and unexpected events resulted in the preservation and repetition of the topic in daily headlines, thus in fact accelerating the rate by 
which Finns renounced the church in spite of the explicitly contrary standpoint of newspapers. This case demonstrates that the media logic cannot be boiled down to the opinions of individual media professionals or even to the views of media outlets generally. Likewise, this case demonstrates why the theorisation of media and its procedures, mechanics and habits, jointly with actual media content, is relevant for the study of the media's role in leaving religion.

Another dimension of mediatisation is how media takes the place of religion. Effects of mediatisation include the reduction of the time people spend with religious institutions and the decline of the need for such institutions. That is, media offers a substitute and constitutes a new framework for meaning, or "sacred canopy" (Berger 1990). If media operates increasingly as a space of meaning-making, it eventually robs one typical function of the religious framework. In this sense, it can be argued that the more media has an influence on individuals' lives, the more likely they are to find the religious context irrelevant. However, media also produces and reproduces religious imagery constituting popular narratives and detached symbols (Hjarvard 2012: 34-39). These weakly institutionalised and somewhat individualised and aestheticised forms in turn offer a new religious identity for some, but the development is concomitant with the more general argument about media's overall detrimental role to institutionalised religion. This is because the media uproots established religious symbols from their traditions and institutions and the attachment to other, more recent religious forms is typically weak, often expressed by fascination and interest rather than by commitment.

In addition to theorising media logics and its possible contribution to individuals leaving religion, one can focus on the discourses, representations and narratives media produces about religion. By media discourses relevant to the leaving of religion, I do not mean only news stories and features about individuals who leave religion but also the overall portrayal of religion and non-religion in media that altogether provide a set of information, images and stories and thus potentially affect people's relation to religion.

When an individual leaves a dominant tradition or church, there is no news story. Individuals are interesting only if they are celebrities, politicians, controversial critics, "career apostates" or the like (Foster 1984; Royle 2012; Larsson 2016). However, when people leave the dominant church en masse, then there is a story for the media to cover and assess. This applies to specific events that prompt people to leave religion as well as to wider social developments. An example of the former is the aforementioned trend of the renunciation of the Evangelical-Lutheran Church of Finland in 2010 following its public statements on the rights of homosexuals. Despite the mainstream media's relatively 
positive attitude towards the Lutheran Church, the newsworthiness of the mass renunciations widely prolonged the crisis, prompting Finns to evaluate whether or not they wanted to preserve their church membership. An example of the latter surrounds "the rise of nones" in the US and in Europe. The fact that the media have started to write about "nones" as if they had formed a cohesive group or community (see Bullard 2016) potentially presents people with a new identification that had otherwise been rather marginal a couple of decades ago. It is well known that "nones" are a very heterogeneous group (Lipka 2015; Woodhead 2016): some hold strong religious beliefs but do not have an affiliation, some atheists strongly reject all religious beliefs and actively campaign against religions. Nevertheless, when the media writes about "the rise of the nones," backed up by recent statistical data, the narrative creates a coherence and identity that is alluring to those who consider leaving religion.

A further complication is that groups labelled as "sects" or "cults" in the media are treated differently from mainstream churches. In such a case, an individual's decision to leave the group is potentially relevant to the media, as an interview with such an individual offers the opportunity to valorise concerns about control, protection, government intervention and the possibility of brainwashing. Media stories about individuals leaving groups deemed closed, conservative, oppressive and otherwise suspicious offer protreptic models for those involved and function as reminders of the dangers of such "cults." Indeed, scholars have suggested that there is clear media bias against New Religious Movements (Beckford 1985; Richardson and van Driel 1997; van Driel and Richardson 1988); the media acts as if it were an authority on acceptable religions, condoning the renunciation of less acceptable ones.

Media discourse about leaving established minority religions, on the other hand, is more ambiguous. Leaving Buddhism, Hinduism or Judaism is not usually the media's primary interest, but the situation is different in the case of Islam. Western media has proven to have an insatiable appetite for stories about people leaving Islam, partly because of support groups and activist organisations for ex-Muslims in social media, such as the Council of Ex-Muslims of Britain, the Ex-Muslims of North America and WikiIslam (Larsson 2007; Enstedt and Larsson 2013; Cottee 2015). For instance, the Finnish public broadcasting company's story “Fatima gave up Islam, but cannot remove her veilleaving Islam is a taboo in Finland" (Vatanen 2016) was significant because of the uniqueness of its tale. The article told of two ex-Muslims of Somali background who were still wearing the veil, because they were afraid that their family and relatives would not approve otherwise. These women discovered a Finnish ex-Muslim's blog, which encourage them now to speak in the national 
media about being ex-Muslims. Although the article offered a sympathetic view on the trials and tribulations of ex-Muslims, recapitulating the problems they have experienced, it was not attempting to paint Islam in broad strokes. Rather, the article was typical in its defence of individual choices- that Islam is one among many possibilities that should be allowed to be chosen from in the same open way that leaving Islam should be a viable option without having to weather pressure from the religious group or relatives of the same faith.

One of the significant aspects in the media's involvement is what kind of publicity is given to non-religious people and organisations. Studies suggest that, while atheist activists are often covered in media, the media does not always approve of their mission. Richard Dawkins, for instance, is a frequent face on media, but he is often perceived as too aggressive, provocative and uninformed in his views about religion (Knott et al. 2013; Taira 2015). This suggests that, while the media gives space for critical voices, it does not necessarily encourage people to leave religion, except in cases where the religious group in question is considered too limiting, repressive or conservative- that is, in comparison to the media's relatively liberal values. The sheer presence of such stories about non-religious people and their activities, however, is likely to keep fast the possibility of leaving religion in people's minds. Non-religious organisations are thus keen on their campaigns gaining media visibility.

One of the most famous campaigns is the atheist bus campaign which ran the slogan "There's Probably No God. Now Stop Worrying and Enjoy Your Life" in its original UK form in 2009 and, in a slightly amended form, in thirteen other countries (Tomlins and Bullivant 2017). It is difficult to estimate how influential such campaigns have been, but, based on individual testimonies, they have contributed to some people becoming non-religious (Cimino and Smith 2014; Kontala 2016).

The campaigns fostered momentum for people leaving religion, but they always come with the risk of unintended consequences. The media narrative is often delicate, and there are times when neutral or somewhat positive coverage turns sour. One example of such a campaign can be found in 2010, when Finnish Freethinkers replicated the example in the US of the Atheist Agenda offering Hustler magazines in exchange for religious books at the University of Texas, San Antonio. The same public stunt, swapping porn magazines for Bibles, was frowned upon in the Finnish public sphere, not only by the media but also by many activists in non-religious organisations (Taira 2012: 31-32).

Although the media is not opposed to religion in general (Knott et al. 2013), some media companies co-operate with those who wish for people to leave religion. One interesting example is Richard Dawkins, whose purpose is 
consciousness-raising and helping people to come out as atheists. Dawkins has featured in many antireligious documentaries shown on the main television channels in Britain and are widely available on DVD and YouTube.

Similar antireligious discourses are present in social media without the mediation of traditional media companies and houses. Blogs, for instance, are easily available for those thinking of leaving religion. Some websites, such as WikiIslam, focus on particular tradition, while others campaign for atheism in general. An example of the latter is Pharyngula, administrated by biology professor PZ Myers. The blog conjures up an image of conflict between religion and science, one in which everyone must choose a side: "Science and religion are two different ways of looking at the universe and changing the world, and I believe that you must set one aside to follow the other." (Myers 2013: 146). This is one of the ways in which media discourses offer alternative points of identification-science, in this case-for those who do not identify with a particular faith.

The analysis of media discourses supports the idea that the overall media logic contributes to the media's liberalising effect, but it does not mean that media is antireligious as such. While media discourses are powerful, they are rarely the sole factor that motivates someone to leave any given religion. Hence, it is necessary to explore how people utilise media, particularly social media, to achieve a better understanding of how the media facilitates and influences people's decisions to leave religion.

Online environments create favourable circumstances for small religious groups to disseminate their message and reach potentially interested people without the mediation of mainstream media. Furthermore, it provides the space for like-minded people to seek information not otherwise featured on mainstream media (Campbell 2010; Taira 2013: 213). However, the same holds true for people interested in leaving religion. Just as Muslims post their conversion narratives on the internet (van Nieuwkerk 2014), so do people who leave any religious tradition (Enstedt and Larsson 2013). Similarly, just as the internet has been dubbed a "recruitment tool for cults" (Rick Ross, quoted in Cowan 2014: 698), there is equally evidence for people leaving religion because of opportunities opened up by free online access to information and like-minded people.

A useful example about the significance of media in general and social media in particular can be found in the example of people who have left Conservative Læstadianism in Finland. Læstadianism is a Lutheran revival movement that started in Lapland in the middle of the nineteenth century. In the twenty first century, the movement has been under scrutiny by the liberal media, partly because of practices in the faith perceived as oppressive. The 
movement is also somewhat closed, with problems typically being dealt within the community, without involvement from outsiders, the police or a secular court of justice. Members usually also cut ties with people who abandon the movement.

Stories by former Læstadians on the internet empower individuals on the brink of leaving the movement. When people write anonymously in a discussion forum, they find that other people have had similar experiences and concerns. This sharing of narratives encourages such individuals to come out in public, and the mainstream media, in turn, is eager to publish their stories and explore the cases further, forcing leaders of the group to comment on accusations made in the public. The ensuing publicity and scandal further empower those who have been nursing doubts that they have yet acted on to share their viewpoints (Hintsala 2016; Rova 2016.). The opportunities offered by online environments to members of the movement create an accretion of scandal, aided from the outside by the media. Despite the crucial role of the online environment, the decision to leave religion usually necessitates some kind of face-to-face contact with people that can be trusted (Richardson 2014: 745). In the case of Læstadianism, apostates have noted public speeches, partisan associations and scholarly writings as facilitators relevant to their decision to leave the movement (Rova 2016).

Another example is an American 21-year-old, "Lynnette," a former Evangelical Christian who writes about how her brother came out on his Facebook page as an atheist, which in turn helped her to "separate actual atheist beliefs from the stigma against atheism" (Lynnette 2014: 38). After a couple of months, she began to explore atheist blogs and concluded that atheists, too, can be good people. When Lynnette had been an atheist for almost two years, she thought that she was still only halfway out of the closet. She has mentioned her atheism on Facebook profile information, but has been afraid to announce it elsewhere. (Lynnette 2014: 38-39). This example includes both trusted people and lesser-known blog contributors, demonstrating that media matters, though it is not the sole factor operating behind one's choice to leave religion.

The role media plays in facilitating apostasy is further evidenced among former Mormons in America. A study of people leaving Mormonism confirms three relevant aspects of the online environment: first, even innocent queries for information lead to "anti-Mormon" websites that can sow seeds of doubt and serve as catalysts for people to abandon the religion; second, online communities of former Mormons can function as sanctuaries in which people can share their stories with like-minded people, get recognition for their new exMormon identity and sustain themselves in a new community; third, rather than offering a neutral space for individuals to share their stories, the websites 
encourage "users to post their 'exit stories' and to offer 'support' to one another" (Avance 2013: 21).

Interviews with people affiliated to non-religious organisations reveal that some have found inspiration for leaving religion and joining non-religious activities by watching Dawkins on YouTube or reading books on atheism (Kontala 2016: 109). While the book has been an important medium for a long time, the online environment has become increasingly relevant in recent years in empowering and inspiring people to come out as atheists (Cimino and Smith 2014). In addition to watching and reading online about non-religiosity and atheism, people find websites sharing information about the experiences of their peers. For example, on the website of Richard Dawkins, the Foundation for Science and Reason, is a Convert's Corner-a page where users can leave testimonies on how they became non-religious and read about the experiences of others. As of the beginning of 2017, more than 2000 testimonies are published there.

User testimonies can also be found on select Facebook groups. One particularly interesting example is the Facebook page of the film Religulous (2008). On 4 October 2013, the administrator posted the following message: "Religulous opened 5 yrs ago today; still religious people in the world (damn!) but to thousands who told me they quit, congrats and Thank YOU!." Users commented on this in many ways. In addition to praise and stories about attempts to convert others, some offered testimonies about the film's life-changing experience, such as the following: "I honestly have to thank you, because I saw this movie when I was 13 and it changed my life. Thank you for questioning every religion. I'm a big fan and congratulations."

Yet another example is The Institute for the Secularisation of Islamic Societies, which mainly opposes Islam as a political doctrine not as a personal faith, though the institute nevertheless supports people leaving Islam. Even in their classic publication, Leaving Islam (Warraq 2003), the institute advertised their own website, including a list of websites where assistance and support could be found. They understood the potential of the online environment in these matters already at the beginning of twenty first century. More recently, the importance of the internet and social media in the Islamic context has been emphasised by Brian Whitaker, who suggests that non-believers in the Middle East have "begun to find a voice" and "social media have provided them with the tools to express themselves." (Whitaker 2014:5). Although there are broader demands for political and social changes that come with the interest in leaving religion, the development of media technology and easy access thereto means that "young Arabs today are far more aware of the outside world than previous generations and, when they hold up their own countries to the mirror, many 
dislike what they see" (Whitaker 2014: 6). Leaving Islam, facilitated by media use, is one possible response to this cognitive dissonance.

The potential power of individuals' media use is also recognized by state officials, since "most of those arrested for 'defaming' religion have got[ten] into trouble as a result of their internet activity" (Whitaker 2014: 27). The significance of the internet is further emphasised by an ex-Muslim, Ali A. Rizvi, the author of The Atheist Muslim (2016), who claims to have received "thousands of emails" from atheist Muslims (or people wishing to become one but cannot do so in public). He suggests that especially young people are now interconnected, and they are "getting access to ideas through the Internet. They are becoming more skeptical." (Rizvi 2017).

Given the ubiquity of mediated information about the possibilities of leaving religion and supporting networks, it has become clear that the outside of religion is not somewhere "out there" but rather "here" - available after a couple of clicks. It is not simply the easy accessibility of information; the online environment allows people to imagine themselves as potentially a part of a non-religious community (Cottee 2015). As Cimino and Smith (2014: 64) put it, "the substantial transformations in our contemporary communication technologies are creating a new way for atheists to come out, speak out, and meet up in a still largely religious society." This does not explain why individuals leave religion, but it does suggest that it would be unwise not to consider the role played by the consumption of media and communication technologies in the process of leaving religion.

\section{3}

Methodological Perspectives and Turning Points

The methods for studying the role of media and communication in leaving religion are not very different from standard humanistic and social scientific methods. However, some methods are more suitable than others for studying the different aspects highlighted in this chapter.

First, the study of media logics calls for methods that help grapple with the roles and functions of media institutions generally and also the relationship between the media and other institutions in contemporary society. The most appropriate way to study media logics in relation to leaving religion is the development of theories based on case studies. Second, media discourses can be studied by utilising standard qualitative methods such as discourse analysis, content analysis and narrative analysis. It is also possible to add quantitative content analysis to the methodical repertoire, particularly if the hypothesis is that the availability of certain kinds of stories pertaining to religion affects 
people's decisions to leave religion. Third, media use can be analysed by means of ethnographic methods, such as interviews, observation, media ethnography and audience research. Furthermore, the increased digitalisation of society and the growing significance of the online environment carry methodological implications. Netnography, online surveys, video analysis and digital methods operating with "big data" are likely to increase in the near future.

It would be unrealistic to propose that an individual researcher would be able to cover all the aspects highlighted in this chapter. From the individual's point of view, it is rather a question of singling out the most relevant and interesting approach, hoping that different studies will cumulatively foster a dialogue that results in a more coherent and rigorous understanding of the role media plays in leaving religion. In addition to an exploration of the individual testimonies people share on such websites as Dawkins's Convert's Corner and WikiIslam, a more general study of the media's role could proceed in two steps.

The first step would be to investigate what role, if any, the media plays in people's decisions to leave religion. Although media ethnography is often enough for studying the role of media use, one option would be to collect writings by people who have left religion, and select for interviews individuals in whose writings the role of media has been addressed directly.

The second step would be to explore media coverage of leaving religion. Although there are plenty of studies focusing on media discourses, representations and narratives pertaining to religion, few studies investigate the way the media covers the leaving of religion.

Together, these two steps could provide building blocks for a more comprehensive understanding of media logics, media discourses and media use in relation to the study of leaving religion.

I have suggested that the significance of the role played by media in leaving religion has not been examined thoroughly enough. However, if the assertions about the ubiquity of media are to be believed, it can be expected that media will become more relevant in the future. There is thus a need for studies to specify which roles media play in leaving religion, but it may be more precise to anticipate that media are becoming common factors in facilitating people's decisions but also in creating new circumstances in which various options emphasising individual choice are introduced. Therefore, it is likely that the study of leaving religion will have to take media and communications into consideration in order to understand apostates in general. 
This chapter has outlined various focal points for the study of the role of media and communication in leaving religion and suggested some methods. This inclusion of a variety of media means that thinking about media convergence is significant for future studies. Convergence means simply the "coming together of things that were previously separate" (Meikle and Young 2012: 2), while media convergence refers specifically to "the flow of content across multiple media platforms, the cooperation of media industries, and the migratory behaviour of media audiences" (Jenkins 2008: 2). What this means in the context of studying leaving religion is that researchers have to pay attention to the interplay of various media - newspapers, radio, television, social media and other online environments at the levels of media logics and discourses-as well as the multiple ways people use them. While specific media technologies privilege some opportunities over others, as suggested by traditional medium theory, the media convergence means that no single medium exists in a vacuum.

One possible example to highlight media convergences and combine the three areas examined in this chapter-usage, discourses and media logicswould be the Finnish website Eroa kirkosta ("Divorce from the Church") and the role it plays in people giving up faith. At the level of media use, it has been shown that most Finns who resigned from the church in recent times have done so through this website. ${ }^{2}$ Furthermore, through the website, people have familiarised themselves with associations and networks that support those without a religion. At the level of media discourse, it would be relevant to focus on the strong public presence of the website in the mainstream media. The website publishes press releases with information pertaining to the number of apostates and reasons people give for leaving the church. Often, documents prompt other media outlets to publish stories about resignations, referring to the website's press releases-quoting reasons from testimonies and the statistical data published there-with little alteration. This likewise offers a glimpse into the media logic. Writing stories about mass resignations is considered relevant news material; it is cheap news production for media houses, as reliable data and sound bites are provided in the press release, and the message of the press release - that is leaving religion if you have any reason to do so-is not too far from the liberal standpoint of the mainstream media.

This example suggests a more general point: it is not simply the media that matters but the articulations between media and people's social practices. The

1 https://eroakirkosta.fi/dynamic/index.php/ Accessed 25/02/2019.

2 https://en.wikipedia.org/wiki/Eroakirkosta.fi Accessed 25/02/2019. 
media is an integral part of the ways in which people practice their religiosity, but also their considerations to leave religion, and opens up opportunities for people who wish to leave their religion, though the media is rarely the primary factor for doing so. Media help people find information and seek out support; this fact underlines the significance of thinking about how media is articulated in the process of leaving religion.

\section{References}

Altheide, D.L., and Snow, R.P. 1979. Media logic. London: Sage.

Arthur, C., ed. 1993. Religion and the Media: An Introductory Reader. Cardiff: University of Wales Press.

Avance, R. 2013. "Seeing the Light: Mormon Conversion and Deconversion Narratives in Off- and Online Worlds." Journal of Media and Religion. 12, 16-24.

Beckford, J.A. 1985. Cult Controversies: The Societal Response to the New Religious Movements. London: Tavistock.

Berger, P. 1990. The Sacred Canopy: Elements of a Sociological Theory of Religion. New York: Doubleday.

Bullard, G. 2016. “The World's Newest Major Religion: No Religion.” National Geographic, 22 April 2016.

Campbell, H. 2010. When Religion Meets New Media. London: Routledge.

Castells, M. 2002. The Rise of the Network Society. Second edition. Oxford: Blackwell.

Cimino, R. and Smith, C. 2014. Atheist Awakening: Secular Activism and Community in America. New York: Oxford University Press.

Cottee, S. 2015. The Apostates: When Muslims Leave Islam. London: Hurst \& co.

Cowan, D.E. 2014. Conversion to New Religious Movements. In L.R. Rambo and C.F. Farhadian, eds, The Oxford Handbook of Religious Conversion. Oxford: Oxford University Press, 687-705.

Enstedt, D., and Larsson, G. 2013. "Telling the Truth about Islam? Apostasy Narratives and Representation of Islam on WikiIslam.net." CyberOrient 7:1.

Foster, L. 1984. "Career Apostates: Reflections on the Works of Jerald and Sandra Tanner." Dialogue: A Journal of Mormon Thought. 17:2, 35-60.

Herbert, D.E.J. 2011. "Theorising Religion and Media in Contemporary Societies: An Account of Religious 'Publicization." European Journal of Cultural Studies. 14:6, $626-648$.

Hintsala, M-A.E. 2016. "Weary and Grateful: The Power of Expressed Emotions on the Internet among Conservative Laestadians." Journal of Religion, Media and Digital Culture. 5:2, 356-375. 
Hjarvard, S. 2012. "Three Forms of Mediatized Religion: Changing the Public Face of Religion." In S. Hjarvard and M. Lövheim, eds, Mediatization of Religion: Nordic Perspectives. Gothenburg: Nordicom, 21-44.

Hjarvard, S. 2013. The Mediatization of Religion and Culture. London: Routledge.

Hoover, S.M., and Lundby, K. eds 1997. Rethinking Religion, Media and Culture. London: Sage.

Jenkins, H. 2008. Convergence Culture. New York: New York University Press.

Knott, K., Poole, E., and Taira, T. 2013. Media Portrayals of Religion and the Secular Sacred: Representation and Change. Farnham: Ashgate.

Kontala, J. 2016. Emerging Non-religious Worldview Prototypes: A Faith-Q-sort-study on Finnish Group-affiliates. Turku: Åbo Akademi University Press.

Larsson, G. 2007. “Cyber-Islamophobia? The Case of WikiIslam.” Contemporary Islam. $1: 1,53-67$.

Larsson, G. 2011. Muslims and the New Media: Historical and Contemporary Debates. Farnham: Ashgate.

Larsson, G. 2016. "Most Muslims are Like You and I, but 'Real Muslims...” Ex-Muslims and Anti-Muslim Sentiments." Journal of Muslims in Europe. 5:2, 205-223.

Lipka, M. 2015. "Religious 'Nones' Are Not Only Growing, They're Becoming More Secular." Pew Research Center. At http://www.pewresearch.org/fact-tank/2015/11/11/ religious-nones-are-not-only-growing-theyre-becoming-more-secular/. Accessed 30/4/2019.

Lynnette. 2014. "Religion and the F-Word (Feminism)." In M.E. Brewster, ed., Atheists in America. New York: Columbia University Press, 31-39.

Lynch, G. and Mitchell, J. with A. Strhan, eds. 2012. Religion, Media and Culture: A Reader. London: Routledge.

Meikle, G. and Young, S. 2012. Media Convergence: Networked Digital Media in Everyday Life. Basingstoke: Palgrave.

Mitchell, J. and Marriage, S., eds. 2003. Mediating Religion: Conversations in Media, Religion and Culture. London: T\&T Clark.

Myers, P.Z. 2013. The Happy Atheist. New York: Vintage.

Rambo, L.R. and Farhadian, C.F. eds 2014. The Oxford Handbook of Religious Conversion. Oxford: Oxford University Press.

Richardson, J.T. 2014. "Legal and Political Issues and Religious Conversion." In L.R. Rambo and C.F. Farhadian, eds, The Oxford Handbook of Religious Conversion. Oxford: Oxford University Press, 736-755.

Richardson, J.T. and van Driel, B. 1997. 'Journalists' Attitudes Toward New Religious Movements." Religious Studies Review. 39:2, 116-136.

Rizvi, A.A. 2016. The Atheist Muslim: A Journey from Religion to Reason. New York: St Martin's Press. 
Ritzvi, A.A. 2017. "The Danger of Admitting You're an Atheist Muslim. An Interview with Mary Hynes." CBC Radio, 8 January 2017.

Rova, M-L. ed. 2016. Uskonsota keittiössä. Vanhoillislestadiolaisuudesta erkaantuneiden kokemuksia. Helsinki: Gummerus.

Royle, R. 2012. "Popular Media, News and Religion." In J. Mitchell and O. Gower, eds, Religion and the News. Farnham: Ashgate, 153-16o.

Taira, T. 2012. "More Visible but Limited in its Popularity: Atheism (and Atheists) in Finland." Approaching Religion. 2:1, 21-35.

Taira, T. 2013. "Does the 'Old' Media's Religion Coverage Matter in Times of Digital Religion?” In T. Ahlbäck, ed., Digital Religion. Turku: Donner Institute for Religious and Cultural History, 204-221.

Taira, T. 2015. "Media and the Nonreligious." In K. Granholm, M. Moberg and S. Sjö, eds, Religion, Media, and Social Change. London: Routledge, 110-125.

Tomlins, S. and Bullivant, S.C. eds 2017. The Atheist Bus Campaign: Global Manifestations and Responses. Leiden: Brill.

van Driel, B. and Richardson, J. 1988. "Print Media Coverage of New Religious Movements: A Longitudinal Study." Journal of Communications. 38, 37-61.

van Nieuwkerk, K. 2014. "Conversion" to Islam and the Construction of a Pious Self. Lewis R. Rambo and Charles F. Farhadian (eds), The Oxford Handbook of Religious Conversion. Oxford: Oxford University Press, 667-686.

Vatanen, P. 2016. "Fatima luopui islamista, mutta ei voi riisua huivia - islamista eroaminen on Suomessa tabu." Yle News 28 May 2016.

Warraq, I. [pseud] ed. 2003. Leaving Islam: Apostates Speak Out. Amherst: Prometheus Books.

Whitaker, B. 2014. Arabs Without God: Atheism and Freedom of Belief in the Middle East. Create Space Independent Publishing Platform.

Woodhead, L. 2016. "The Rise of 'No Religion' in Britain: The Emergence of a New Cultural Majority." Journal of the British Academy. 4, 245-261. 